\title{
Organic zinc absorption by the intestine of broilers in vivo
}

\author{
$\mathrm{Yu} \mathrm{Yu}{ }^{1,2}$, Lin $\mathrm{Lu}^{1}$, Su-Fen $\mathrm{Li}^{1,3}$, Li-Yang Zhang ${ }^{1}$ and Xu-Gang Luo ${ }^{1 *}$ \\ ${ }^{1}$ Mineral Nutrition Research Division, Institute of Animal Science, Chinese Academy of Agricultural Sciences, Beijing 100094, \\ People's Republic of China \\ ${ }^{2}$ Xinhua Hospital, Shanghai Jiao Tong University School of Medicine, Shanghai 200092, People's Republic of China \\ ${ }^{3}$ Hebei Normal University of Science and Technology, Changli 066600, People's Republic of China \\ (Submitted 4 February 2017 - Final revision received 6 April 2017 - Accepted 7 April 2017 - First published online 22 May 2017)
}

\section{Abstract}

In Expt 1, a Zn-unsupplemented basal diet (control) and the basal diet supplemented with one of four different $\mathrm{Zn}$ sources, including $\mathrm{ZnSO}$, Zn-amino acid chelate with a weak chelation strength (Zn-AA W), Zn-protein chelate with a moderate chelation strength (Zn-Pro M) and Zn-protein chelate with a strong chelation strength (Zn-Pro S) were fed to broiler chickens from days 14 to 28 . On day 28 , Zn content in plasma from the hepatic portal vein increased $(P<0.05)$ in the following order: control $<\mathrm{ZnSO}_{4}<\mathrm{Zn}-\mathrm{AA}$ W $<\mathrm{Zn}-\mathrm{Pro} \mathrm{M}<\mathrm{Zn}$-Pro $\mathrm{S}$. Meanwhile, metallothionein (MT) mRNA levels in the duodenum, jejunum and ileum were enhanced $(P<0 \cdot 05)$ by $Z n$ addition regardless of Zn source. However, no differences among different Zn sources were observed. In Expt 2, ligated duodenal loops from Zn-deficient broilers (28-d old) were perfused with solutions containing $0-2.464 \mathrm{mmol} \mathrm{Zn/1} \mathrm{from} \mathrm{the} \mathrm{above-mentioned} \mathrm{four} \mathrm{Zn}$ sources for up to $30 \mathrm{~min}$. The uptake kinetics of $\mathrm{Zn}$ followed a saturable carrier-mediated process. The maximum absorption velocity values were in the following order: control $<\mathrm{ZnSO}_{4}<\mathrm{Zn}$-AA W $<$ Zn-Pro M $<$ Zn-Pro S. Moreover, MT mRNA levels for Zn-Pro S $(P<0 \cdot 03)$, Zn-Pro M $(P>0 \cdot 05)$ and Zn-AA W $(P<0.04)$ were higher than those for $\mathrm{ZnSO}_{4}$. These findings indicate that organic $\mathrm{Zn}$ absorption (especially $\mathrm{Zn}$-Pro $\mathrm{S}$ ) in intact living broilers was more effective than that of inorganic $\mathrm{Zn}$; organic $\mathrm{Zn}$ absorption in the ligated duodenal segment was a saturable carrier-mediated process similar to that of $\mathrm{ZnSO}_{4}$. Moreover, except for MT, there might be other $\mathrm{Zn}$ transporters involved in $\mathrm{Zn}$ absorption that are affected by different Zn sources.

\section{Key words: Kinetics: Organic zinc absorption: Metallothionein: Small intestine: Broiler chickens}

$\mathrm{Zn}$ is a trace element essential for life. Zn deficiency impairs growth, immune activity and reproductive function; however, $\mathrm{Zn}$ can also be toxic if over-accumulated ${ }^{(1)}$. The $\mathrm{Zn}$ stores in avians are easily depleted, and thus $\mathrm{Zn}$ is commonly supplemented in diets for poultry. The use of organic trace mineral supplements in the feed industry has increased during the last 20 years. However, the results on whether the absorption of organic $\mathrm{Zn}$ is more effective than that of inorganic $\mathrm{Zn}$ in rats, pigs, dogs and humans are inconsistent ${ }^{(2-5)}$. Our previous data have demonstrated that organic $\mathrm{Zn}$ absorption in three small intestinal segments of broilers was more effective than that of inorganic $\mathrm{Zn}$, and increased with increasing chelation strength (defined as the quotient of formation $\left(Q_{\mathrm{f}}\right)$, which is a quantitative measurement of complex or chelation strength between metal and ligand) ${ }^{(6,7)}$. In addition, organic $\mathrm{Zn}$, especially that with strong chelation strength, could lessen the negative effect of phytate on $\mathrm{Zn}$ absorption in ligated small intestinal segments, and showed higher $\mathrm{Zn}$ absorption under a high level of phytate $^{(8)}$. However, the findings from this half-in vivo study need to be verified by in vivo studies of broilers. To our knowledge, no in vivo study has been reported on the influence of organic and inorganic $\mathrm{Zn}$ sources on $\mathrm{Zn}$ absorption in the gut of animals.

An earlier study performed with broilers in our laboratory showed that the kinetics of inorganic $\mathrm{Zn}$ absorption followed a saturable carrier-mediated process in either the duodenum or the jejunum, but a non-saturable diffusion process in the ileum, depending on the regulation of $\mathrm{Zn}$ transporter expression ${ }^{(7)}$. However, whether the absorption mechanism of organic $Z n$ differs from that of inorganic $\mathrm{Zn}$ in poultry remains largely unknown. In addition, metallothionein (MT) is believed to function in the transport and sequestration of $\mathrm{Zn}$ by intracellular vesicles ${ }^{(9,10)}$, and we previously found that it participated in regulating inorganic $\mathrm{Zn}$ absorption $^{(7)}$. However, whether MT is involved in organic $\mathrm{Zn}$ absorption has not been elucidated with a kinetic absorption study before, and thus it needs to be further explored using the ligated duodenal loops of broilers, as MT has been shown to be mainly expressed in the duodenum of broilers ${ }^{(9,10)}$.

Abbreviations: Zn-AA W, Zn-amino acid chelate with a weak chelation strength; Zn-Pro M, Zn-protein chelate with a moderate chelation strength; Zn-Pro S, Zn-protein chelate with a strong chelation strength.

* Corresponding author: Professor X.-G. Luo, fax +86106281 0184, email wlysz@263.net 
Table 2. Composition of two diets for 1-28-d-old broilers in Expt 2 (as-fed basis)

\begin{tabular}{|c|c|c|}
\hline & \multicolumn{2}{|c|}{ Periods } \\
\hline & Days $1-21$ & Days 22-28 \\
\hline \multicolumn{3}{|l|}{ Ingredients (\%) } \\
\hline Ground yellow maize & 52.33 & \\
\hline Soyabean meal & $37 \cdot 00$ & \\
\hline Fishmeal & 4.02 & \\
\hline DL-Met & 0.15 & \\
\hline Maize starch & & $66 \cdot 00$ \\
\hline Casein & & 23.00 \\
\hline Cellulose & & 5.07 \\
\hline Soyabean oil & 3.40 & 1.30 \\
\hline Calcium carbonate* & 1.15 & 1.65 \\
\hline Calcium hydrogen phosphate* & 1.35 & 1.12 \\
\hline Sodium chloride* & 0.30 & 0.30 \\
\hline Micronutrients $†$ & 0.30 & 1.56 \\
\hline \multicolumn{3}{|l|}{ Nutrient composition } \\
\hline Metabolisable energy (MJ/kg) & $12 \cdot 51$ & $13 \cdot 15$ \\
\hline Crude protein (\%)‡ & $22 \cdot 90$ & 20.46 \\
\hline Lys (\%) & 1.22 & 1.69 \\
\hline Met (\%) & 0.58 & 0.62 \\
\hline Met + Cys (\%) & 0.92 & 0.72 \\
\hline $\mathrm{Ca}(\%) \ddagger$ & 1.17 & 0.98 \\
\hline Non-phytate P (\%) & 0.47 & 0.40 \\
\hline Zn (mg/kg)‡ & $96 \cdot 42$ & $14 \cdot 61$ \\
\hline
\end{tabular}

* Reagent grade.

† Provided per kg of diet: for days 1-21 - vitamin A (all-trans retinol acetate), $4.46 \mathrm{mg}$; vitamin $\mathrm{D}_{3}$ (cholecalciferol), $0.9 \mathrm{mg}$; vitamin $\mathrm{E}$ (all-rac-a-tocopherol acetate), $33 \mathrm{mg}$; vitamin $\mathrm{K}$ (menadione sodium bisulfite), $6 \mathrm{mg}$; thiamine (thiamine mononitrate), $4.5 \mathrm{mg}$; riboflavin, $10.5 \mathrm{mg}$; vitamin $B_{6}, 6 \mathrm{mg}$; vitamin $B_{12}, 0.03 \mathrm{mg}$; calcium pantothenate, $18 \mathrm{mg}$; niacin, $60 \mathrm{mg}$; folic acid, $1.8 \mathrm{mg}$; biotin, $0.165 \mathrm{mg}$; choline (choline chloride), $1000 \mathrm{mg}$; $\mathrm{Cu}\left(\mathrm{CuSO}_{4} .5 \mathrm{H}_{2} \mathrm{O}\right), 8 \mathrm{mg} ; \mathrm{Zn}\left(\mathrm{ZnSO}_{4} .7 \mathrm{H}_{2} \mathrm{O}\right), 60 \mathrm{mg}$ $\mathrm{Mn}\left(\mathrm{MnSO}_{4} \cdot \mathrm{H}_{2} \mathrm{O}\right), 100 \mathrm{mg} ; \mathrm{Fe}\left(\mathrm{FeSO}_{4} \cdot 7 \mathrm{H}_{2} \mathrm{O}\right), 80 \mathrm{mg} ; \mathrm{I}(\mathrm{KI}), 0.35 \mathrm{mg} ; \mathrm{Se}$ $\left(\mathrm{Na}_{2} \mathrm{SeO}_{3}\right), 0.15 \mathrm{mg}$; for days 22-28 - vitamin A (all-trans retinol acetate), $4.46 \mathrm{mg}$; vitamin $\mathrm{D}_{3}$ (cholecalciferol), $0.9 \mathrm{mg}$; vitamin $\mathrm{E}$ (all-rac-a-tocopherol acetate), $33 \mathrm{mg}$; vitamin $\mathrm{K}$ (menadione sodium bisulfite), $6 \mathrm{mg}$; thiamine (thiamine mononitrate), $4.5 \mathrm{mg}$; riboflavin, $10.5 \mathrm{mg}$; vitamin $B_{6}, 6 \mathrm{mg}$; vitamin $B_{12}, 0.03 \mathrm{mg}$; calcium pantothenate, $18 \mathrm{mg}$; niacin, $60 \mathrm{mg}$; folic acid, $1.8 \mathrm{mg}$; biotin, $0.165 \mathrm{mg}$; choline (choline chloride), $700 \mathrm{mg} ; \mathrm{K}(\mathrm{KCl}), 3000 \mathrm{mg} ; \mathrm{Mg}\left(\mathrm{MgSO}_{4} \cdot 7 \mathrm{H}_{2} \mathrm{O}\right)$, $600 \mathrm{mg} ; \mathrm{Cu}\left(\mathrm{CuSO}_{4} \cdot 5 \mathrm{H}_{2} \mathrm{O}\right), 8 \mathrm{mg} ; \mathrm{Fe}\left(\mathrm{FeSO}_{4} \cdot 7 \mathrm{H}_{2} \mathrm{O}\right), 80 \mathrm{mg} ; \mathrm{Mn}\left(\mathrm{MnSO}_{4} \cdot \mathrm{H}_{2} \mathrm{O}\right)$, $100 \mathrm{mg}$; I (KI), $0.35 \mathrm{mg} ; \mathrm{Se}\left(\mathrm{Na}_{2} \mathrm{SeO}_{3}\right), 0.15 \mathrm{mg}$. $\ddagger$ Determined values.

to feed and to tap water containing an undetectable amount of $\mathrm{Zn}$ in both experiments.

\section{Ligated loop procedure}

In Expt 2, all 28-d-old birds were fasted overnight, and then weighed to equalise the body weights in all groups. The detailed in situ ligated duodenal surgical operation procedure was performed according to a previous protocol ${ }^{(7)}$. The solutions injected into the ligated duodenal loops were buffered with $15.5 \mathrm{mmol} / 1$ of morpholinoethanesulfonic acid at $\mathrm{pH} 6$. Different $\mathrm{Zn}$ sources were added to the media to obtain the desired $\mathrm{Zn}$ concentrations. Phenol red was a non-absorbable marker used for correcting the changes in $\mathrm{Zn}$ concentration resulting from water absorption or intestinal secretion. The content of phenol red in perfusion solutions was $20 \mathrm{mg} / \mathrm{l}^{(7,14)}$.

\section{Sample collection and preparation}

In Expt 1, on days 21 and 28, three birds per cage for each of the five treatments were selected according to the average body weight of the cage and anaesthetised by intravenous injections of $\mathrm{Na}$ pentobarbital $(20 \mathrm{mg} / \mathrm{kg}$ body weight) via a wing vein. The blood sample was collected from the hepatic portal vein, and plasma was separated. The samples were pooled for each cage, resulting in eight composite samples per treatment, and then frozen $\left(-20^{\circ} \mathrm{C}\right)$ for analysing the concentrations of $\mathrm{Zn}$. After blood collection, one bird from each replicate cage for each treatment was killed and the intestinal mucosa was collected from three small intestinal segments of the bird as described by Bai et $a l .{ }^{(15)}$, immediately frozen in liquid $\mathrm{N}_{2}$ and stored at $-70^{\circ} \mathrm{C}$ for detecting the MT mRNA expression.

In Expt 2, an optimal sampling time of $30 \mathrm{~min}$ after the injection of solutions was used as established in our previous study ${ }^{(7)}$. Each treatment was repeated ten times using ten birds. The ligated duodenal loop of each bird was considered as one replication. A volume of $2 \mathrm{ml}$ of perfusion solution was collected from the ligated duodenal loop of each bird and frozen $\left(-20^{\circ} \mathrm{C}\right)$ for analysing the concentrations of $\mathrm{Zn}$ and phenol red. Then, all birds from the control and $0.616 \mathrm{mmol} \mathrm{Zn/l} \mathrm{groups}$ were killed, and their ligated duodenal loops were immediately excised and rinsed with ice-cold saline, and then the intestinal mucosa was scraped from the underlying submucosa with a sterile glass slide. The mucosa samples were frozen in liquid $\mathrm{N}_{2}$ for detecting the mRNA expression levels of MT.

\section{Determinations of zinc and phenol red concentrations}

Zn concentrations in diets, plasma and perfusion solutions were determined by inductively coupled plasma emission spectroscopy (model IRIS Intrepid II; Thermo Jarrell Ash) ${ }^{(7)}$. The concentrations of phenol red in perfusion solutions were assayed by measuring absorbency at 520, 560 and $600 \mathrm{~nm}$ with a UV-Vis spectrophotometer (model Cary 100; Varian, Inc.) ${ }^{(16)}$. Final volumes of solutions and absorption velocities of $\mathrm{Zn}$ were calculated according to the following equations:

$$
\begin{aligned}
& V_{\mathrm{F}}=\frac{C_{\mathrm{P}(1)} \times V_{\mathrm{I}}}{C_{\mathrm{P}(2)}} \\
& U V=\frac{C_{\mathrm{Zn}(1)} \times V_{\mathrm{I}-C_{\mathrm{Zn}(2)} \times V_{\mathrm{F}}},}{T \times L},
\end{aligned}
$$

where $V_{\mathrm{F}}$ is the final volume of perfusion solution $(\mathrm{ml}) ; C_{\mathrm{P}(1)}$ and $C_{\mathrm{P}(2)}$ the initial and final concentrations $(\mathrm{mg} / \mathrm{l})$ of phenol red, respectively; $V_{\mathrm{I}}$ the initial volume $(\mathrm{ml})$ of injected dose; $U V$ the absorption velocity of $\mathrm{Zn}(\mathrm{nmol} / \mathrm{min}$ per $\mathrm{cm}) ; C_{\mathrm{Zn}(1)}$ and $C_{\mathrm{Zn}(2)}$ the $\mathrm{Zn}$ concentrations $(\mathrm{mmol} / \mathrm{l})$ of the initial and final perfusion solutions, respectively; $T$ the sampling time (min) after initiation of dosing; and $L$ the length $(\mathrm{cm})$ of the ligated intestinal segment.

\section{Quantitative real-time PCR procedure}

In order to determine the mRNA expression levels of MT in intestinal mucosa samples by real-time PCR, MT-specific primers were designed using the software of Primer Premier 5.0, and the sequences were as follows: Forward 5'-AAG GGC TGT GTC TGC AAG GA-3', Reverse 5'-CTT CAT CGG TAT GGA AGG TAC AAA-3'. The protocols of RNA isolation, reverse 
transcription and real-time PCR were the same as those used in our previous study ${ }^{(7)}$.

\section{Statistical analyses}

The data were processed using Statistical Analysis Systems version 8.2 (SAS Institute). In Expt 1, analysis of the data was performed using two-way ANOVA with the general linear model. The model for plasma $\mathrm{Zn}$ content in the hepatic portal vein included the effects of $\mathrm{Zn}$ source, age and their interaction. The model for MT mRNA levels included the effects of $\mathrm{Zn}$ source, intestinal segment and their interaction. The replicate cage or individual chick served as the experimental unit. In Expt 2, the data of MT mRNA levels in the ligated duodenal loops perfused with solutions containing 0 (control) and $0.616 \mathrm{mmol} \mathrm{Zn} / \mathrm{l}$ from one of the $\mathrm{Zn}$ sources were subjected to one-way ANOVA using the general linear model, with each loop as the experimental unit. The differences in kinetic parameters obtained from different Zn sources were analysed by Student's $t$ test. For all data, when ANOVA was significant, post hoc comparisons of treatment means were made using the least-squares mean test. Statistical significance was detected at $P<0.05$.

The kinetic analysis of $\mathrm{Zn}$ absorption was performed by fitting the data obtained from Expt 2 to the following equations: the first-order equation (a non-saturable diffusive component, Equation (1)), the Michaelis-Menten equation (a saturable process, Equation (2)) or two components including both equations mentioned above (a saturable process plus a nonsaturable diffusive component, Equation (3) $)^{(17)}$ :

$$
\begin{gathered}
J_{\mathrm{Zn}}=P A, \\
J_{\mathrm{Zn}}=\frac{J_{\max } A}{K m+A}, \\
J_{\mathrm{Zn}}=\frac{J_{\max } A}{K m+A}+P A,
\end{gathered}
$$

where $J_{\mathrm{Zn}}$ is the absorption velocity of $\mathrm{Zn} ; J_{\max }$ is the maximum velocity in $\mathrm{nmol} / \mathrm{min}$ per $\mathrm{cm} ; K m$ is in $\mathrm{mmol} / \mathrm{l} ; P$ the diffusive constant in $\mathrm{cm}^{2} / \mathrm{min}$ and $A$ the concentration of $\mathrm{Zn}$ in $\mathrm{mmol} / \mathrm{l}$.

The fits of experimental data to the equations were carried out using a non-linear least-square regression program (SigmaPlot version 9.0; SPSS Inc.). To select the best kinetic model of $\mathrm{Zn}$ absorption in this research, the Akaike information criterion (AIC) ${ }^{(18,19)}$ has been adopted. The model with the smallest AIC was regarded as the 'best' model as it minimised the difference of the given model from the 'true' model. We have also considered the $\mathrm{CV}$ of the parameter obtained after each fit.

\section{Results}

Effect of four zinc sources on zinc content in plasma from the hepatic portal vein and body weights of broilers (Expt 1)

Significant differences $(P<0.0001)$ among treatments were observed in plasma $\mathrm{Zn}$ content from the hepatic portal vein on days 21 and 28 of this experiment, but the effects of age (d) and treatment $\times$ age interaction were NS $(P>0 \cdot 14)$ (Table 3 ). On day $21, \mathrm{Zn}$ content in plasma was increased $(P<0.005)$ by
Table 3. Effect of dietary zinc source on zinc content in plasma from the hepatic portal vein of 21- and 28-d-old chicks (Expt 1) (Mean values with their standard errors; $n 8$ )

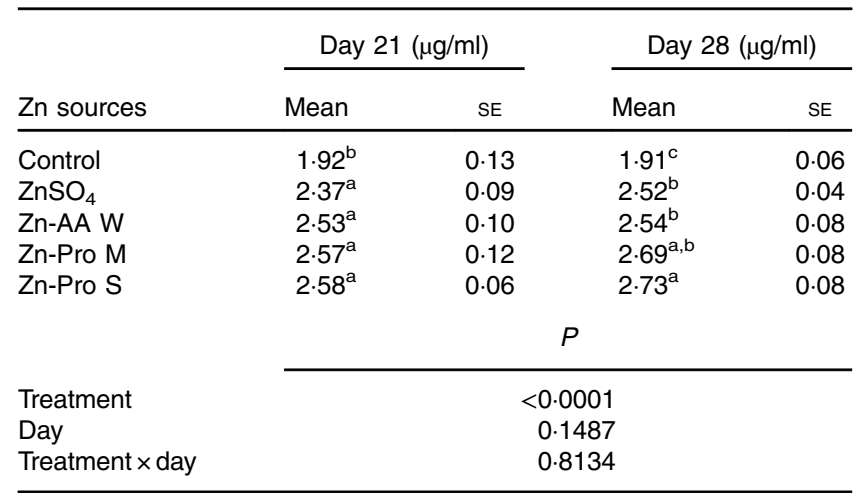

Zn-AA W, Zn-amino acid chelate with a weak chelation strength $\left(Q_{\mathrm{f}}, 6.48\right) ; \mathrm{Zn}$-Pro M, $\mathrm{Zn}$-protein chelate with a moderate chelation strength $\left(Q_{\mathrm{f}}, 30.73\right)$; Zn-Pro $\mathrm{S}$, $Z n$-protein chelate with a strong chelation strength $\left(Q_{f} 944.02\right)$.

a,b,c Mean values within a column with unlike superscript letters were significantly different $(P<0.05)$.

23.44 to $34.48 \%$ for $\mathrm{ZnSO}_{4}, \mathrm{Zn}$-AA W, Zn-Pro M and Zn-Pro S treatments, compared with the control, with no differences $(P>0 \cdot 15)$ among different $\mathrm{Zn}$ sources. However, $\mathrm{Zn}$ content in plasma was numerically $6 \cdot 75-8 \cdot 86 \%$ higher for organic $\mathrm{Zn}$ sources with different chelation strength than for $\mathrm{ZnSO}_{4}$. On day 28, Zn content in plasma was increased $(P<0 \cdot 0001)$ by 31.94 to $42.93 \%$ for $\mathrm{ZnSO}_{4}, \mathrm{Zn}$-AA W, Zn-Pro M and Zn-Pro S treatments, compared with the control group. Plasma $Z n$ content was 7.48 and $8.33 \%$ higher $(P<0.05)$ for $Z n$-Pro S than for $\mathrm{Zn}-\mathrm{AA} \mathrm{W}$ and $\mathrm{ZnSO}_{4}$, respectively. There were no differences $(P>0 \cdot 21)$ among $\mathrm{ZnSO}_{4}, \mathrm{Zn}-\mathrm{AA} \mathrm{W}$ and $\mathrm{Zn}$-Pro $M$ treatments. These findings showed that the absorption of $\mathrm{Zn}$ as $\mathrm{Zn}$-Pro $\mathrm{S}$ was higher than that of $\mathrm{Zn}$ from $\mathrm{ZnSO}_{4}, \mathrm{Zn}-\mathrm{AA} \mathrm{W}$ and $\mathrm{Zn}$-Pro M in the intestine of broilers. In addition, the mean body weights of these birds on either day 21 or day 28 were not affected ( $P>0.24$ ) by the $\mathrm{Zn}$ sources, and were 758 (sE 23), 745 (sE 23), 741 (SE 28), 759 (SE 29) and 740 (SE 29) g/bird on day 21, and 1021 (sE 26), 1048 (se 29), 1025 (se 39), 1049 (sE 29) and 1013 (se 36) g/bird on day 28 for the control, $\mathrm{ZnSO}_{4}, \mathrm{Zn}-\mathrm{AA} \mathrm{W}$, Zn-Pro $\mathrm{M}$ and Zn-Pro $\mathrm{S}$ treatments, respectively.

mRNA expression levels of metallothionein in the duodenum, jejunum and ileum of intact living broilers as affected by four zinc sources (Expt 1)

The Zn source significantly affected $(P<0 \cdot 0001)$ MT mRNA expression levels in the duodenum, jejunum and ileum of 4 -week-old broilers as shown in Fig. 1. Different $\mathrm{Zn}$ sources significantly up-regulated $(P<0 \cdot 0001)$ MT mRNA expression levels in three small intestinal segments of broilers compared with the control group without $\mathrm{Zn}$ addition. However, the differences among different $\mathrm{Zn}$ sources were not observed $(P>0.27)$ in the duodenum and ileum. In the jejunum, MT mRNA expressions for $\mathrm{Zn}-\mathrm{AA} W(P<0.0300)$ and $\mathrm{ZnSO}_{4}$ $(P=0.0500)$ were significantly higher than those for Zn-Pro M, and there were no significant differences $(P>0.46)$ among $\mathrm{ZnSO}_{4}, \mathrm{Zn}-\mathrm{AA} \mathrm{W}$ and $\mathrm{Zn}$-Pro $\mathrm{S}$, nor between $\mathrm{Zn}-\mathrm{AA} \mathrm{M}$ and Zn-Pro $S$. In addition, the changes of MT mRNA levels regulated 


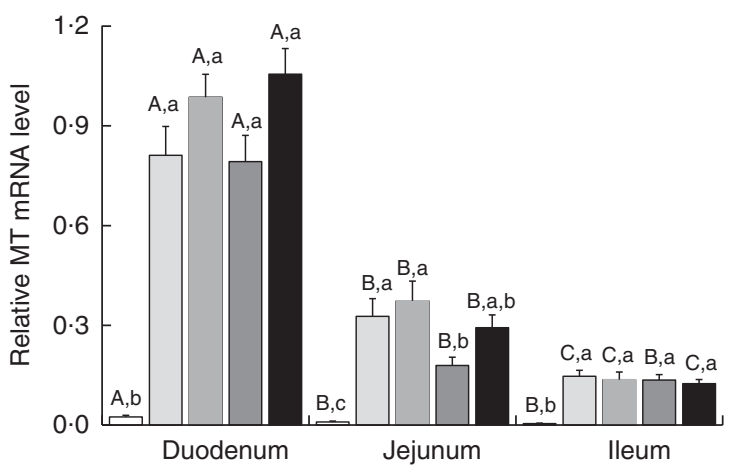

Fig. 1. Effect of zinc source on metallothionein (MT) mRNA expression levels in different small-intestinal segments of intact chicks (Expt 1). The zincdeficient chicks (14-d old) were fed the basal diet (control ( $\square$ ); containing about $28 \mathrm{mg}$ zinc/ $/ \mathrm{kg}$ ) or the basal diet supplemented with $60 \mathrm{mg}$ zinc/kg from either $\mathrm{ZnSO}_{4}(\square)$, or one of three organic zinc sources with weak (Zn-AA W ( $\square$ ), $Q_{\mathrm{f}}$ 6.48), moderate (Zn-Pro $\mathrm{M}(\square), Q_{\mathrm{f}} 30.73$ ) and strong (Zn-Pro $S(\square)$, $Q_{\mathrm{f}}$ 944.02) chelation strength for $14 \mathrm{~d}$, respectively. MT mRNA levels were determined by real-time quantitative PCR. Data are presented in arbitrary units as relative mRNA abundances normalised to $\beta$-actin transcript abundance. Values are means $(n 8)$, with their standard errors represented by vertical bars. Zinc source, intestinal segment and their interaction all had significant effects $(P<0.0001){ }^{a}{ }^{\mathrm{a}, \mathrm{b}, \mathrm{c}}$ Mean values with unlike superscript letters were significantly different $(P<0.05)$ among different zinc sources for the same intestinal segment. $A, B, C$ Mean values with unlike superscript letters were significantly different $(P<0.05)$ among different intestinal segments for the same source.

by the same $\mathrm{Zn}$ source in different small intestinal segments were very sharp $(P<0 \cdot 0001)$. MT mRNA expressions in the ileum that were affected by different $\mathrm{Zn}$ sources were significantly lower $(P<0.001)$ than those in the duodenum and jejunum, and sharply lower $(P<0.003)$ in the jejunum than in the duodenum, except for no significant differences $(P>0 \cdot 16)$ between the jejunum and ileum in MT mRNA levels of the control and Zn-Pro M treatment. These results indicate that dietary supplementations with different $\mathrm{Zn}$ sources obviously increased MT mRNA expression levels in the duodenum, jejunum and ileum of broilers. In addition, the effect of $\mathrm{Zn}$ source on MT mRNA expressions in the jejunum was significant, and no differences were found in the other two small intestinal segments. Moreover, regardless of $\mathrm{Zn}$ source, MT mRNA expression levels were the highest in the duodenum, but the lowest in the ileum.

\section{Kinetic absorption of organic and inorganic zinc in the ligated duodenum (Expt 2)}

The kinetic $\mathrm{Zn}$ absorption of different $\mathrm{Zn}$ sources was investigated within a wide $Z n$ concentration range (Fig. 2). We found that $\mathrm{Zn}$ absorption was improved with increasing $\mathrm{Zn}$ concentrations regardless of $\mathrm{Zn}$ source. The regression analyses showed that the best fits for $\mathrm{Zn}$ absorption from different $\mathrm{Zn}$ sources in ligated duodenal loops were to Equation (2). It means that organic $\mathrm{Zn}$ absorption is a saturable carriermediated process in duodenal loops, which is similar to the inorganic $\mathrm{Zn}$ absorption process. The kinetic parameters obtained, $J_{\max }$ and $K m$, are outlined in Table 4 . The $K m$ values were higher for Zn-AA W, Zn-Pro M and Zn-Pro S than for the $\mathrm{ZnSO}_{4}(6 \cdot 85,7.14$ and $7.57 v 4.53 \mathrm{mmol} / \mathrm{l})$, but the differences were NS $(P>0.05)$. The different $K m$ values demonstrate that the carriers involved in regulating $\mathrm{Zn}$ absorption from different Zn sources may be different, because different carriers have different affinities with $\mathrm{Zn}$. The $J_{\max }$ values were obviously greater $(P<0 \cdot 01)$ for the Zn-AA W, Zn-Pro M and Zn-Pro $S$ than for the $\mathrm{ZnSO}_{4}(22.01,30.47$ and $30.74 v .11 .39 \mathrm{nmol} / \mathrm{min}$ per $\mathrm{cm})$, with no differences $(P>0 \cdot 38)$ among organic $\mathrm{Zn}$ sources, suggesting that $\mathrm{Zn}$ absorption from organic $\mathrm{Zn}$ sources might be higher than that from the inorganic $\mathrm{Zn}$ source. In addition, organic $\mathrm{Zn}$ sources with greater $Q_{\mathrm{f}}$ values tended to have a higher Zn absorption.

\section{mRNA expression levels of metallothionein in the ligated duodenum as affected by four zinc sources (Expt 2)}

The MT mRNA expression levels in the ligated duodenum of 4 -week-old broilers were significantly affected $(P<0.05)$ by the $\mathrm{Zn}$ source as shown in Fig. 3. Compared with the control group, the perfusions of organic $\mathrm{Zn}$ sources significantly up-regulated $(P<0.05)$ MT mRNA levels in the ligated duodenum, and they were about $1 \cdot 5-2 \cdot 1$ times of those in the control group. The MT mRNA levels were significantly higher $(P<0.04)$ for the $\mathrm{Zn}$-Pro $\mathrm{S}$ group than for the $\mathrm{Zn}$-Pro $\mathrm{M}$ and $\mathrm{ZnSO}_{4}$ groups, and for the $\mathrm{Zn}$-AA W group than for the $\mathrm{ZnSO}_{4}$ group. However, no differences $(P>0 \cdot 22)$ were observed between the control and $\mathrm{ZnSO}_{4}$ groups, the $\mathrm{ZnSO}_{4}$ and $\mathrm{Zn}$-Pro $\mathrm{M}$ groups, the $\mathrm{Zn}-\mathrm{AA} \mathrm{W}$ and $\mathrm{Zn}$-Pro $M$ groups or the $\mathrm{Zn}-\mathrm{AA} \mathrm{W}$ and $\mathrm{Zn}$-Pro $\mathrm{S}$ groups. These data demonstrate that organic Zn sources, especially Zn-Pro S, boosted MT transcriptional expressions in the duodenum of broilers.

\section{Discussion}

$\mathrm{Zn}$ is absorbed from intestinal-mucosal cells and subsequently transported to the portal blood of the liver, and albumin is the main plasma carrier that is involved in this removal process $^{(20,21)}$. Thus, $\mathrm{Zn}$ content in plasma of the hepatic portal vein can accurately reflect the differences in $\mathrm{Zn}$ absorption from different $\mathrm{Zn}$ sources. We investigated the effect of different $\mathrm{Zn}$ sources on $\mathrm{Zn}$ content in plasma of the hepatic portal vein using intact living broilers, and found that the absorption of $\mathrm{Zn}$ from organic $\mathrm{Zn}$ sources was higher than that of $\mathrm{Zn}$ from the inorganic $\mathrm{Zn}$ source, and the absorption of $\mathrm{Zn}$ from the $\mathrm{Zn}$-Pro $\mathrm{S}$ was higher than that of $\mathrm{Zn}$ from $\mathrm{ZnSO}_{4}, \mathrm{Zn}-\mathrm{AA} \mathrm{W}$ and $\mathrm{Zn}$-Pro M. These results are similar to our previous findings on Mn content in plasma from the hepatic portal vein of broilers, in which the absorption of $\mathrm{Mn}$ from the organic Mn source with strong chelation strength was higher than that of Mn from either $\mathrm{MnSO}_{4}$ or the organic $\mathrm{Mn}$ source with weak or moderate strength in broilers ${ }^{(22)}$. In addition, we have previously reported that the absorption of $\mathrm{Zn}$ as organic $\mathrm{Zn}$ was more effective than that of $\mathrm{Zn}$ as inorganic $\mathrm{Zn}^{(8)}$. Organic $\mathrm{Zn}$ absorption increased with increasing chelation strength as well. Moreover, organic $\mathrm{Zn}$ sources could lessen the negative effect of phytate on $\mathrm{Zn}$ absorption; further, the absorption of organic $\mathrm{Zn}$, especially of Zn-Pro S, was more effective than that of inorganic $\mathrm{Zn}$ under a high level of phytate ${ }^{(8)}$. The data acquired using intact living 




(a)

(c)

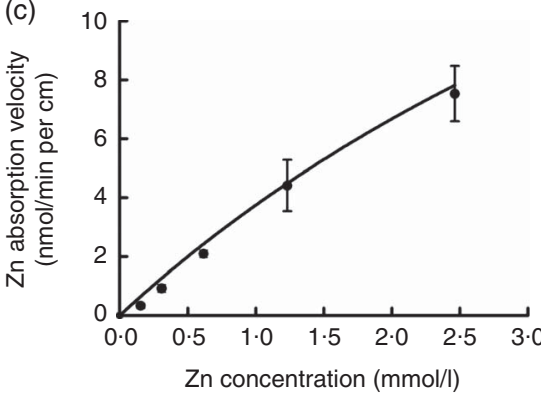

(b)

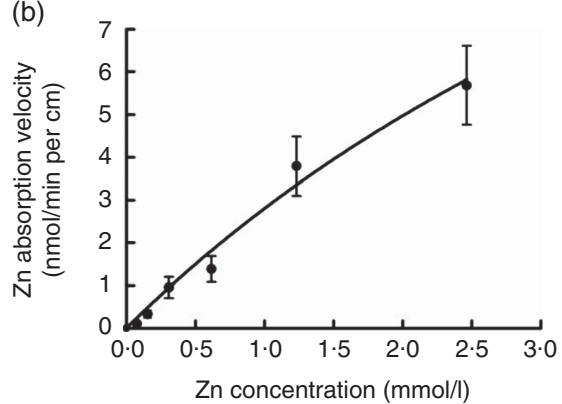

(d)

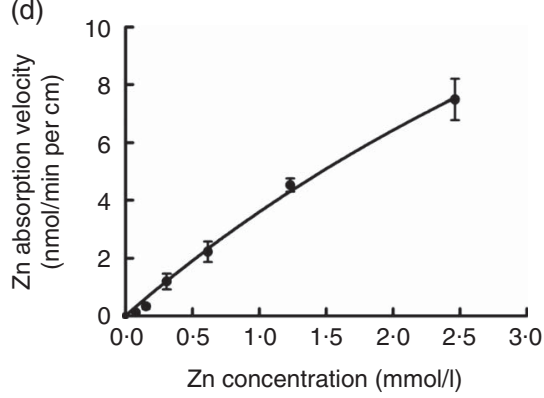

Fig. 2. Kinetic absorption of zinc from different zinc sources in the ligated duodenal loops of zinc-deficient chicks (Expt 2). The ligated duodenal loops were perfused with solutions containing $0.077-2.464 \mathrm{mmol}$ zinc/l from either (a) $\mathrm{ZnSO}_{4}$, or one of three organic zinc sources with (b) weak (Zn-AA W, $Q_{\mathrm{f}} 6.48$ ), (c) moderate (Zn-Pro M, $Q_{\mathrm{f}} 30.73$ ) and (d) strong (Zn-Pro S, $Q_{\mathrm{f}}$ 944.02) chelation strength, respectively. At 30 min after perfusion, zinc transport (disappearance of zinc from the ligated duodenal loop) was determined and the initial rate of zinc transport was calculated. Values of zinc transport rates are means $(n 8)$, and standard deviations represented by vertical bars. All kinetic curves of zinc transport from different zinc sources in the duodenum are described by the Michaelis-Menten equation (a saturable process).

Table 4. Kinetic and statistical parameters obtained after fitting Michaelis-Menten equations to the experimental data of zinc uptake in the ligated duodenal loops of chicks (Expt 2)

(Mean values with their standard errors; $n$ 8)

\begin{tabular}{|c|c|c|c|c|c|c|}
\hline \multirow[b]{3}{*}{ Zn sources } & \multicolumn{4}{|c|}{ Kinetic parameters } & & \\
\hline & \multicolumn{2}{|c|}{$\begin{array}{c}J_{\max } \\
(\mathrm{nmol} / \mathrm{min} \text { per } \mathrm{cm})\end{array}$} & \multicolumn{2}{|c|}{$\begin{array}{c}\mathrm{Km} \\
(\mathrm{mmol} / \mathrm{l})\end{array}$} & \multicolumn{2}{|c|}{ Statistical parameters } \\
\hline & Mean & $\mathrm{SE}$ & Mean & SE & $R^{2}$ & AIC \\
\hline $\mathrm{ZnSO}_{4}$ & $11 \cdot 39^{b}$ & $1 \cdot 77$ & 4.53 & 0.95 & 0.93 & $1 \cdot 28$ \\
\hline $\mathrm{Zn}-\mathrm{AA}$ W & $22 \cdot 01^{\mathrm{a}}$ & 3.75 & 6.85 & 1.63 & 0.92 & 1.73 \\
\hline Zn-Pro M & $30 \cdot 47^{a}$ & 4.72 & $7 \cdot 14$ & 1.74 & 0.96 & 1.75 \\
\hline Zn-Pro S & $30 \cdot 74^{a}$ & 4.68 & 7.57 & 1.76 & 0.97 & 1.26 \\
\hline
\end{tabular}

$J_{\max }$, maximum absorption velocity of $\mathrm{Zn}$; AIC, Akaike information criterion; $\mathrm{Zn}-\mathrm{AA} \mathrm{W}$, $\mathrm{Zn}$-amino acid chelate with a weak chelation strength $\left(Q_{\mathrm{f}}, 6.48\right)$; Zn-Pro $\mathrm{M}$, $\mathrm{Zn}$-protein chelate with a moderate chelation strength $\left(Q_{\mathrm{f}}, 30.73\right)$; Zn-Pro S, $Z n$-protein chelate with a strong chelation strength $\left(Q_{\mathrm{f}}, 944 \cdot 02\right)$.

a,b Mean values within a column with unlike superscript letters were significantly different $(P<0.05)$.

broilers in the present study confirmed the above results obtained from in situ ligated small intestinal loops of broilers.

There are two assumptions about the absorption mechanisms of mineral complexes. One is that 'complexed' or 'chelated' trace minerals are absorbed in their intact form, and the metal atoms remain safely bound or protected within organic molecular structures or 'ligands' during absorption. The other is that organic ligands can prevent the harmful effect of competitive ligands such as phosphate, phytate and other compounds, which can bind free metal ions and render the minerals unavailable for absorption. Maintaining a dietary mineral in solution allows maximum



Fig. 3. Effect of zinc source on metallothionein (MT) mRNA expression levels in the ligated duodenal loops of zinc-deficient chicks at 30 min after perfusion as determined by real-time quantitative PCR (Expt 2). The treatments included a zinc-free basal solution (control) and the basal solution supplemented with $0.616 \mathrm{mmol}$ zinc/l (close to the dietary requirement of $90 \mathrm{mg}$ zinc/ $\mathrm{kg}$ for broilers) from either $\mathrm{ZnSO}_{4}$, or one of three organic zinc sources with weak (Zn-AA W, $Q_{\mathrm{f}}$ 6.48), moderate (Zn-Pro $\mathrm{M}, Q_{\mathrm{f}}$ 30.73) and strong (Zn-Pro $\mathrm{S}, Q_{\mathrm{f}}$ 944.02) chelation strength, respectively. Data are presented in arbitrary units as relative mRNA abundances normalised to $\beta$-actin transcript abundance. Values are means $(n 8)$, with their standard errors represented by vertical bars. ${ }^{a, b, c, d}$ Mean values with unlike superscript letters were significantly different $(P<0.05)$ among different zinc sources.

opportunity for contact with intestinal mucosa, and then $\mathrm{Zn}$ from a Zn-ligand complex or chelate may undergo dissociation to a high-affinity site on the brush-border membrane ${ }^{(23,24)}$. Koike et al. ${ }^{(25)}$ suggest that the Zn-EDTA complex be transported from the chicken lumen to the plasma intactly because the 
content of ${ }^{65} \mathrm{Zn}$ in plasma is equal to that of ${ }^{14} \mathrm{C}$. This is in agreement with the work of Suso \& Edwards ${ }^{(26)}$ and Hempe \& Cousins ${ }^{(27)}$. Wapnir et al. ${ }^{(28)}$ found that the Zn-L-histidine complex could be absorbed in its intact form by perfused rat intestines in the same way as histidine. Lowe et $a l .{ }^{(29)}$ studied the absorption and retention of $\mathrm{Zn}$ administered as ZnMet chelate in dogs, and found that the coefficients determined for absorption were closer to those determined for the absorption of amino acids, thus supporting the fact that $\mathrm{Zn}$ as an amino acid chelate is transported across the intestinal enterocyte and into the circulation in an intact form. However, there are many reports providing evidence to support the second assumption that organic Zn could be absorbed as $\mathrm{Zn}$ ions. Hill et al. ${ }^{(2,3)}$ demonstrated that the ${ }^{14} \mathrm{C},{ }^{3} \mathrm{H}$ and ${ }^{65} \mathrm{Zn}$ content in the everted rat gut, which were used to mark ${ }^{65}$ ZnMet $\left({ }^{14} \mathrm{C}\right)$ and ${ }^{65}$ ZnLys $\left({ }^{3} \mathrm{H}\right)$ chelates, were not equal. Therefore, the $\mathrm{Zn}$-amino acid complexes or chelates do not appear to be absorbed intactly, and organic $\mathrm{Zn}$ may be dissociated into $\mathrm{Zn}$ ions in the brush-border membrane before absorption. This conclusion was similar to the work of Beutler et $a l^{(5)}$ who found that when equimolar amounts of ${ }^{65} \mathrm{Zn}$ and $\left[{ }^{35} \mathrm{~S}\right]$ methionine were added to cells, the uptake of ${ }^{65} \mathrm{Zn}$ was $>1000$ times the uptake of $\left.{ }^{35} \mathrm{~S}\right]$ methionine. The data support the concept that ZnMet dissociates in solution, and that the metal ion and amino acid are taken up separately. Our previous data demonstrated that Zn-Pro $S$ was the least available, suggesting that it may be difficult to dissociate $\mathrm{Zn}$ from $\mathrm{Zn}$-Pro $\mathrm{S}$ and mobilise it for metabolic utilisation by the body tissue ${ }^{(30,31)}$. In the present study, the absorption of $\mathrm{Zn}$ as $\mathrm{Zn}$-Pro $\mathrm{S}$ was the highest among different $\mathrm{Zn}$ sources. These findings show that $\mathrm{Zn}$ absorption as Zn-Pro S may be in line with the first hypothesis that organic $\mathrm{Zn}$ sources are absorbed in an intact form.

In addition, we investigated the kinetic curve of organic $\mathrm{Zn}$ absorption in the ligated duodenum of the broiler, and found that the patterns of $\mathrm{Zn}$ absorption from the four different $\mathrm{Zn}$ sources all followed the same saturable carrier-mediated process in the duodenum, which is in agreement with the methods of inorganic $\mathrm{Zn}$ absorption reported in our previous study ${ }^{(7)}$. Even so, the $J_{\max }$ values of organic $\mathrm{Zn}$ sources with different chelation strength were significantly higher than those of inorganic $Z n$ sources, and they were 22.01 (Zn-AA W), 30.47 (Zn-Pro M), $30 \cdot 74$ (Zn-Pro S) and $11.39\left(\mathrm{ZnSO}_{4}\right) \mathrm{nmol} / \mathrm{min}$ per $\mathrm{cm}$, respectively, further indicating that the absorption of organic $\mathrm{Zn}$ was better than that of inorganic $\mathrm{Zn}$. In addition, there was a decreased trend of the $\mathrm{Km}$ value for $\mathrm{ZnSO}_{4}$ compared with that for organic $\mathrm{Zn}$ sources, suggesting that the carriers involved in organic $\mathrm{Zn}$ absorption might have a higher affinity for $\mathrm{Zn}$, and this may be the partial reason for organic $\mathrm{Zn}$ absorption being better than inorganic $\mathrm{Zn}$ absorption.

MT is a small, cysteine-rich protein that is especially prevalent in the liver, kidney and intestine. Evidence shows that high ambient concentrations of $\mathrm{Zn}$ could increase MT expression, which can combine and store $\mathrm{Zn}$, or increase the secretion of $\mathrm{Zn}$ from the small intestine to the lumen, and then reduce the absorption of $\mathrm{Zn}^{(10,32-35)}$. However, other researchers reported that MT content in the intestines of mice had no effect on $\mathrm{Zn}$ absorption by administering, gavaging or perfusing $\mathrm{Zn}^{(36,37)}$. In our present study, $\mathrm{Zn}$ supplementation, regardless of the Zn source, significantly increased MT mRNA expression levels in three small intestinal segments of broilers, as seen in Expt 1, which is in agreement with previous data in other animals ${ }^{(12,38-40)}$. Moreover, MT mRNA levels in the duodenum were higher for organic $\mathrm{Zn}$ ( $\mathrm{Zn}-\mathrm{AA} \mathrm{W}$ and $\mathrm{Zn}$-Pro S) than for inorganic Zn in Expt 2. Cao et al. ${ }^{(41)}$ also showed that organic $\mathrm{Zn}$ sources with moderate or strong complex strength slightly up-regulated the MT protein level in the intestine of broilers, compared with the inorganic Zn source. However, Carlson $^{(42)}$ demonstrated that ZnMet added to the diet significantly decreased MT content in the intestinal mucosa of pigs, compared with $\mathrm{ZnO}$. The above disparities might be caused by different experimental animals or $\mathrm{Zn}$ sources used in these studies. In addition, these data are inconsistent with those of Expt 1 which showed that no differences in the duodenal MT mRNA were found among the four different $\mathrm{Zn}$ sources. The different methods of $\mathrm{Zn}$ administration (dietary supplementation $v$. duodenal perfusion) in Expt 1 and Expt 2 might partially explain the inconsistency. Importantly, when MT mRNA levels in the duodenum were higher for the organic $\mathrm{Zn}$ than for the inorganic $\mathrm{Zn}$, then it could not be elucidated why the organic $\mathrm{Zn}$ absorption was better than that of the inorganic $\mathrm{Zn}$ because of the above reports indicating that increasing MT expression could reduce the absorption of $\mathrm{Zn}$. However, Pekarek \& Evans $^{(43,44)}$ found that bacterial infection with lipopolysaccharide promoted the absorption of $\mathrm{Zn}$, while intestinal MT expression also increased, which is in line with our findings. Starcher et al. ${ }^{(45)}$ obtained similar results. In recent years, a number of mammalian $\mathrm{Zn}$ transporters have been molecularly characterised. This has brought about major advances in our understanding of the tight regulation of cellular $\mathrm{Zn}$ homoeostasis and the pivotal roles which $\mathrm{Zn}$ transporters play in a variety of biological events ${ }^{(46,47)}$. Therefore, other $\mathrm{Zn}$ transporters, except for MT, might have also participated in the absorption of $\mathrm{Zn}$ from different $\mathrm{Zn}$ sources; further efforts are needed to characterise these proteins in future studies.

In summary, our results further confirm that organic $\mathrm{Zn}$ absorption is more effective than that of inorganic $\mathrm{Zn}$, and $\mathrm{Zn}$ absorption from organic $\mathrm{Zn}$ sources with strong chelation strength was higher in intact living broilers; organic $\mathrm{Zn}$ absorption in the ligated duodenal segment is a saturable carrier-mediated process similar to that of $\mathrm{ZnSO}_{4}$. Moreover, except for MT, there may be other $\mathrm{Zn}$ transporters involved in $\mathrm{Zn}$ absorption that are affected by different $\mathrm{Zn}$ sources.

\section{Acknowledgements}

The present study was supported by the Key International Cooperation Program of the National Natural Science Foundation of China (project no. 31110103916; Beijing, People's Republic of China), the Research Program of the Key Laboratory of Animal Nutrition (project no. 2004DA125184G1108; Beijing, PR China), the Agricultural Science and Technology Innovation Program (ASTIP-IAS08; Beijing, PR China), the China Agriculture Research System (project no. CARS-42; Beijing, PR China) and the Program of the National Natural Science Foundation of China (project no. 30871798; Beijing, PR China).

Y. Y. and X.-G. L. conceived and designed the research and revised the manuscript; Y. Y., L. L., S.-F. L. and L.-Y. Z. 
performed the experiments; Y. Y., L. L. and S.-F. L. analysed the data; Y. Y. wrote the manuscript.

None of the authors has any conflicts of interest to declare.

\section{References}

1. Yu Y, Wu A, Zhang Z, et al. (2013) Characterization of the GufA subfamily member SLC39A11/Zip11 as a zinc transporter. J Nutr Biochem 24, 1697-1708.

2. Hill DA, Peo ER Jr \& Lewis AJ (1987) Effect of zinc source and picolinic acid on 65Zn uptake in an in vitro continuous-flow perfusion system for pig and poultry intestinal segments. J Nutr 117, 1704-1707.

3. Hill DA, Peo ER Jr \& Lewis AJ (1987) Influence of picolinic acid on the uptake of 65 zinc-amino acid complexes by the everted rat gut. J Anim Sci 65, 173-178.

4. Lowe JA, Wiseman J \& Cole DJ (1994) Zinc source influences zinc retention in hair and hair growth in the dog. J Nutr 124, 2575S-2576S

5. Beutler KT, Pankewycz O \& Brautigan DL (1998) Equivalent uptake of organic and inorganic zinc by monkey kidney fibroblasts, human intestinal epithelial cells, or perfused mouse intestine. Biol Trace Elem Res 61, 19-31.

6. Holwerda RA, Albin RC \& Madsen FC (1995) Chelation effectiveness of zinc proteinates demonstrated. Feedstuffs $\mathbf{6 7}$, $12-13$.

7. Yu Y, Lu L, Luo XG, et al. (2008) Kinetics of zinc absorption by in situ ligated intestinal loops of broilers involved in zinc transporters. Poult Sci 87, 1146-1155.

8. Yu Y, Lu L, Wang RL, et al. (2010) Effects of zinc source and phytate on zinc absorption by in situ ligated intestinal loops of broilers. Poult Sci 89, 2157-2165.

9. Palmiter RD, Cole TB \& Findley SD (1996) ZnT-2, a mammalian protein that confers resistance to zinc by facilitating vesicular sequestration. $E M B O J$ 15, 1784-1791.

10. Davis SR, McMahon RJ \& Cousins RJ (1998) Metallothionein knockout and transgenic mice exhibit altered intestinal processing of zinc with uniform zinc-dependent zinc transporter-1 expression. J Nutr 128, 825-831.

11. Liu ZH, Lu L, Wang RL, et al. (2015) Effects of supplemental zinc source and level on antioxidant ability and fat metabolism-related enzymes of broilers. Poult Sci 94, 2686-2694.

12. Huang YL, Lu L, Luo XG, et al. (2007) An optimal dietary zinc level of broiler chicks fed a corn-soybean meal diet. Poult Sci 86, 2582-2589.

13. National Research Council (1994) Nutrient Requirements of Poultry. Washington, DC: National Academies Press.

14. Schedl HP (1966) Use of polyethylene glycol and phenol red as unabsorbed indicators for intestinal absorption studies in man. Gut 7, 159-163.

15. Bai SP, Lu L, Wang RL, et al. (2012) Manganese source affects manganese transport and gene expression of divalent metal transporter 1 in the small intestine of broilers. Br J Nutr $\mathbf{1 0 8}$ 267-276.

16. Steel L \& Cousins RJ (1985) Kinetics of zinc absorption by luminally and vascularly perfused rat intestine. Am J Physiol 248, G46-G53.

17. Condomina J, Zornoza-Sabina T, Granero L, et al. (2002) Kinetics of zinc transport in vitro in rat small intestine and colon: interaction with copper. Eur J Pharm Sci 16, 289-295.

18. Gagne P \& Dayton CM (2002) Best regression model using information criteria. J Mod Appl Stat Methods 2, 479-488.

19. Akaike H (1986) An information criterion, AIC. Mathem SCi 14, 5-9.
20. Smith KT, Failla ML \& Cousins RJ (1979) Identification of albumin as the plasma carrier for zinc absorption by perfused rat intestine. Biochem J 184, 627-633.

21. Vallee BL \& Falchuk KH (1993) The biochemical basis of zinc physiology. Physiol Rev 73, 79-118.

22. Ji F, Luo XG, Lu L, et al. (2006) Effect of manganese source on manganese absorption by the intestine of broilers. Poult Sci 85, 1947-1952.

23. Ashmead DH (1993) The Role of Metal Amino Acid Chelate, p. 32. Cleveland, $\mathrm{OH}$ : American Academic Press.

24. Oestreicher P \& Cousins RJ (1982) Influence of intraluminal constituents on zinc absorption by isolated, vascularly perfused rat intestine. J Nutr 112, 1978-1982.

25. Koike TI, Kratzer FH \& Vohra P (1964) Intestinal absorption of zinc or calcium-ethylenediaminetetraacetic acid complexes in chickens. Proc Soc Exp Biol Med 117, 483-486.

26. Suso FA \& Edwards HM Jr (1971) Ethylenediaminetetraacetic acid and $65 \mathrm{Zn}$ binding by intestinal digesta, intestinal mucosa and blood plasma. Proc Soc Exp Biol Med 138, 157-162.

27. Hempe JM \& Cousins RJ (1989) Effect of EDTA and zincmethionine complex on zinc absorption by rat intestine. J Nutr 119, 1179-1187.

28. Wapnir RA, Khani DE, Bayne MA, et al. (1983) Absorption of zinc by the rat ileum: effects of histidine and other lowmolecular-weight ligands. J Nutr 113, 1346-1354.

29. Lowe JA, Wiseman J \& Cole DJ (1994) Absorption and retention of zinc when administered as an amino-acid chelate in the dog. J Nutr 124, 2572S-2574S.

30. Huang YL, Lu L, Li SF, et al. (2009) Relative bioavailabilities of organic zinc sources with different chelation strengths for broilers fed a conventional corn-soybean meal diet. J Anim Sci 87, 2038-2046.

31. Huang YL, Lu L, Xie JJ, et al. (2013) Relative bioavailabilities of organic zinc sources with different chelation strengths for broilers fed diets with low or high phytate content. Anim Feed Sci Technol 179, 144-148.

32. Smith KT \& Cousins RJ (1980) Quantitative aspects of zinc absorption by isolated, vascularly perfused rat intestine. J Nutr 110, 316-323.

33. Coppen DE \& Davies NT (1987) Studies on the effects of dietary zinc dose on $65 \mathrm{Zn}$ absorption in vivo and on the effects of $\mathrm{Zn}$ status on $65 \mathrm{Zn}$ absorption and body loss in young rats. BrJ Nutr 57, 35-44.

34. Hoadley JE, Leinart AS \& Cousins RJ (1987) Kinetic analysis of zinc uptake and serosal transfer by vascularly perfused rat intestine. Am J Physiol 252, G825-G831.

35. Hempe JM, Carlson JM \& Cousins RJ (1991) Intestinal metallothionein gene expression and zinc absorption in rats are zinc-responsive but refractory to dexamethasone and interleukin 1 alpha. J Nutr 121, 1389-1396.

36. Flanagan PR, Haist J \& Valberg LS (1983) Zinc absorption, intraluminal zinc and intestinal metallothionein levels in zinc-deficient and zinc-replete rodents. $J$ Nutr $\mathbf{1 1 3}$, 962-972.

37. Olafson RW (1983) Intestinal metallothionein: effect of parenteral and enteral zinc exposure on tissue levels of mice on controlled zinc diets. J Nutr 113, 268-275.

38. Rojas LX, McDowell LR, Cousins RJ, et al. (1995) Relative bioavailability of two organic and two inorganic zinc sources fed to sheep. J Anim Sci 73, 1202-1207.

39. Levenson CW, Shay NF, Hempe JM, et al. (1994) Expression of cysteine-rich intestinal protein in rat intestine and transfected cells is not zinc dependent. J Nutr 124, 13-17.

40. Sandoval M, Henry PR, Luo XG, et al. (1998) Performance and tissue zinc and metallothionein accumulation in chicks fed a high dietary level of zinc. Poult Sci 77, 1354-1363. 
41. Cao JY, Henry PR, Davis SR, et al. (2002) Relative bioavailability of organic zinc sources based on tissue zinc and metallothionein in chicks fed conventional dietary zinc concentrations. Anim Feed Sci Technol 101, 161-170.

42. Carlson MS (1997) The impact of organic and inorganic sources of zinc supplementation on intestinal metall othionein concentration in the nursery pig. J Anim Sci 5, $188 \mathrm{~S}$.

43. Pekarek RS \& Evans GW (1975) Effect of acute infection and endotoxemia on zinc absorption in the rat. Proc Natl Acad Sci U S A 150, 755-758.
44. Pekarek RS \& Evans GW (1976) Effect of leukocytic endogenous mediator (LEM) on zinc absorption in the rat. Proc Natl Acad Sci U S A 152, 573-575.

45. Starcher BC, Glauber JG \& Madaras JG (1980) Zinc absorption and its relationship to intestinal metallothionein. J Nutr 110, 1391-1397.

46. Lichten LA \& Cousins RJ (2009) Mammalian zinc transporters: nutritional and physiologic regulation. Annu Rev Nutr 29, 153-176.

47. Kambe T (2013) Overview of and update on the physiological functions of mammalian zinc transporters. Nibon Eiseigaku Zasshi 68, 92-102. 